\title{
ANALISIS POLA KELUARAN PROTOTIPE SENSOR RASA PORTABLE CAMPURAN LIPID DIOCTYL PHOSPHATE DAN TRIOCTYL METHYL AMMONIUM CHLORIDE
}

\author{
Finta Amalinda \\ Fakultas Kesehatan Masyarakat Universitas Muhammadiyah Palu \\ Jl. Hang Tuah no.114 Palu. Email: Finta274866@gmail.com
}

\begin{abstract}
Portable taste sensor prototype has been fabricated as two channel ion meter and one types of ion selecting membrane. Two channel ion meter were made for pre development of the taste sensor system or as a electronic tongue wich acted as an multi channel ion meter.ion meter was made using IC op-amp LF412 as its amplifier and microcontroller Atmega8535. meanwhile types of the selecting membrane ion were made using variation: mix of lipid diocthyl phosphate (DOP) and triocthyl methyl ammonium chloride (TOMA) with mass ratio respectively 3:7 and 9:1. On this sensor, lipid determines membrane selectivity to particular ions. Output from taste sensor is a electric potential and then it could be compared with electrode potential references. This portable taste sensor prototype is then tested is ability to sensing for 5 types of solution: glucose, $\mathrm{KCl}, \mathrm{HCl}$, quinine, and MSG. Those 5 types represent 5 basic taste: sweet by glucose, salty by KCL, sour by $\mathrm{HCl}$, bitter by quinine, and umami by MSG. Every solution is made using $1 \mathrm{mM} \mathrm{KCl}$ solution and it is variated to be 7 types of concentration. As a result, taste sensor with lipid membrane mixture of 3:7 mixing tend to respon to the anions sample, resulting potential which decreased for every increase in concentration. For membrane with a lipid mixture of 9:1 showed a tendency to respond to the cations sample, resulting potential which increased for every increase in concentration.
\end{abstract}

Key words: taste sensor, ion meter, ion selecting membrane, lipid, diocthyl phosphate, methyl ammonium chloride.

\section{PENDAHULUAN}

Makanan merupakan sumber tenaga bagi manusia. Manusia menggunakan inderanya berupa lidah untuk mengetahui rasa suatu makanan. Rasa makanan terbagi atas lima macam rasa dasar, biasanya rasa manis diwakili oleh glukosa, rasa pahit diwakili oleh kina, rasa asin diwakili oleh $\mathrm{KCl}$, rasa asam diwakili oleh $\mathrm{HCl}$, dan rasa umami diwakili oleh MSG.

Selama ini pengukuran rasa dilakukan dengan metode analisis konvensional dan tester manusia. Metode analisis kimia konvensional misalnya biosensor dan kromatografi, sedangkan metode yang paling umum digunakan adalah tester manusia berupa lidah. Namun dalam metode-metode ini juga ditemukan beberapa kelemahan, diantaranya (kaltsum et al, 2009):

1. Dalam biosensor, terdapat kesulitan untuk menghasilkan sensor yang selektif terhadap jumlah substansi kimia tertentu.

2. Alat kromatografi memiliki nilai ketepatan yang tinggi, namun biaya pengoperasiannya sangat mahal karena memerlukan jasa seorang ahli yang dapat mengoperasikan alat kromatografi tersebut.

3. Pengukuran rasa yang menggunakan panel uji manusia bersifat subjektif dalam menentukan standar mutu. Emosi dan kesehatan penguji akan berpengaruh pada suasana hati dan akan mempengaruhi hasil pengukuran. Untuk mengatasi kelemahan dari metode-metode diatas, maka diperlukan 
suatu metode baru yang mampu menganalisis suatu rasa. Metode tersebut dikenal sebagai sistem sensor rasa (electronic tongue).

Sistem sensor rasa terdiri atas sensor rasa sebagai elektroda kerja, elektroda $\mathrm{Ag} / \mathrm{AgCl}$ dengan single ceramic junction sebagai elektroda referensi dan keluaran dari kedua elektroda akan ditampilkan pada komputer, berupa pola sinyal yang digambarkan menggunakan metode principal component analysis (PCA). Untuk jenis yang sama, pola yang terbentuk akan mirip (secara visual maupun perhitungan kuantitatif).

Sensor rasa terdiri dari beberapa jenis membran lipid yang berfungsi untuk mengubah informasi rasa menjadi sinyal listrik. Lipid yang digunakan sebagai bahan membran yaitu: asam oleat (OA), oleyl amina (Oam) dan desil alkohol (DA), dioctyl phosphate (DOP), dan triocthyl methyl ammonium chloride (TOMA). Selain itu, digunakan pula membran lipid campuran DOP:TOMA dengan perbandingan 3:7, 5:5 dan 9:1 (Toko, 1996).

Keluaran dari sensor ini berupa intensitas rasa yakni pola potensial yang menggambarkan rasa itu sendiri. Aplikasi dari sensor rasa sudah meluas di berbagai bidang. Dibidang farmasi, sensor rasa dimanfaatkan untuk mengetahui tingkat kepahitan obat yakni dari tingkat paling pahit sampai dengan yang kurang pahit. Sensor rasa juga dimanfaatkan untuk mengetahui tingkat kepahitan obat dengan menambahkan zat pemanis dan mengoptimasi tingkat pemanis pada formula cair (Zheng dan melissa, 2006). Di bidang industri, sensor rasa dimanfaatkan untuk memonitoring secara on-line kualitas susu mulai dari proses pengangkutan hingga proses pengemasan dan penyimpanan, hal ini untuk mengurangi resiko kerugian (Winguist et al, 2005). Di bidang biologi, sensor rasa berbasis voltametri digunakan untuk mengenali enam macam mikroorganisme berbeda (Soderstorm et al, 2003).
Selain membran lipid, bagian terpenting dari sistem sensor rasa adalah ion meter. Ion meter berfungsi untuk membaca keluaran membran (berupa potensial listrik), kemuian mengubahnya dalam bentuk igital, lalu diproses oleh pemproses sinyal, dan hasilnya akan ditampilkan pada display.

Manusia menggunakan lidah untuk merasakan suatu makanan atau minuman. Manusia tidak dapat membedakan setiap zat kimia yang terkandung dalam makanan atau minuman tersebut, tetapi dapat mengelompokkan rasa makanan atau minuman itu sendiri. Informasi rasa zat diubah menjadi sinyal listrik yang selanjutnya ditransmisikan sepanjang serat syaraf ke otak, di mana suatu rasa dapat dikenali dan dirasakan. Kekurangan daripada perasa manusia adalah ketika manusia sakit, maka informasi rasa akan menjadi tidak akurat.

Sistem sensor rasa buatan dikenal dengan nama electronic tongue hadir sebagai terobosan baru untuk memperbaiki kelemahan manusia tersebut. Sekarang ini setidaknya ada dua sistem sensor rasa yang berkembang di dunia, yaitu sistem sensor rasa yang berdasarkan potensial dan voltametri (Deng et al, 2008). Sistem sensor rasa berdasarkan potensial pertama kali dikembangkan oleh Toko dan grup risetnya (Toko et al, 1996). Membran yang digunakan oleh Toko sebagai larik sensor terdiri atas delapan jenis lipid. Membran lipid dibuat dengan mencampurkan setiap lipid dengan PVC, plasticizer, dan THF. Membran yang dihasilkan memiliki ketebalan $200 \mu \mathrm{m}$. Adapun kedelapan jenis lipid tersebut seperti yang tercantum pada Tabel 1.

Membran lipid yang terbentuk kemudian dipasang pada elektroda kerja mutikanal. Elektroda kerja dibuat dari kawat perak (Ag) yang dilapisi dengan $\mathrm{AgCl}$ serta diisi dengan larutan $100 \mathrm{mM} \mathrm{KCl}$. Adapun diagram sistem sensor rasa berdasar potensial dapat dilihat pada Gambar 1. 
Amalinda, F. 2016. Analisis Pola Keluaran Prototipe Sensor Rasa Portable Campuran Lipid Dioctyl Phosphate dan Trioctyl Methyl Ammonium Chloride Journal of Sainstek 8(1): 20-30

Tabel 1. Material lipid yang digunaan sebagai lari sensor (Toko et al, 1996)

\begin{tabular}{cl}
\hline Channel sensor & \\
\hline 1 & Decyl Alcohol (DA) \\
2 & Oleic Acid (OA) \\
3 & Diocthyl Phosphate (DOP) \\
4 & Oleyl Amine (Oam) \\
5 & Triocthyl Methyl Ammonium Chloride (TOMA) \\
6 & DOP : TOMA = 3:7 \\
7 & DOP : TOMA = 5:5 \\
8 & DOP : TOMA =9:1 \\
\hline
\end{tabular}

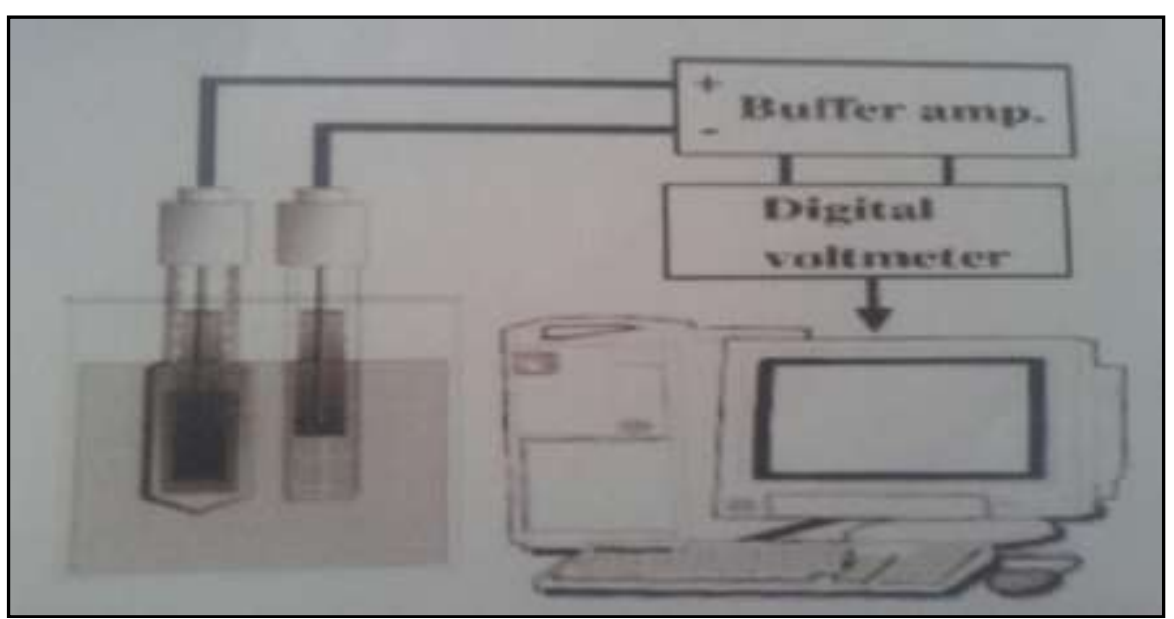

Gambar 1. Skema diagram sistem sensor rasa berdasar potensial (Habara et al, 2003)

Berdasarkan gambar diatas, delapan jenis membran lipid yang diuji coba oleh Toko, diletakkan sekaligus pada elektroda kerja. Setelah elektroda kerja dan elektroda referensi dicelupkan ke dalam larutan sampel (lima macam sampel penghasil rasa dasar), maka akan timbul beda potensial antara kedua elektroda. Perbedaan potensial ini akan diproses oleh buffer dan amplifier, dan hasilnya dapat langsung dilihat di komputer.

Jenis kedua dari electronic tongue adalah berdasar pada voltametri (Winguist et al,
1997). Sistem ini terdiri atas beberapa logam elektroda yang digunakan sebagai elektroda kerja, logam $\mathrm{Ag} / \mathrm{AgCl}$ sebagai elektroda referensi, dan elektroda stainless steel sebagai elektroda pencacah untuk sistem tiga elektroda standar. Voltametri memberikan informasi tentang komposisi larutan elektrolit dengan memplot karakteristik arus/tegangannya. Sistem sensor rasa ini sangat berhasil untuk menganalisis variasi jenis air minum, susu, teh, jus dan pertumbuhan jamir dalam media cair. 


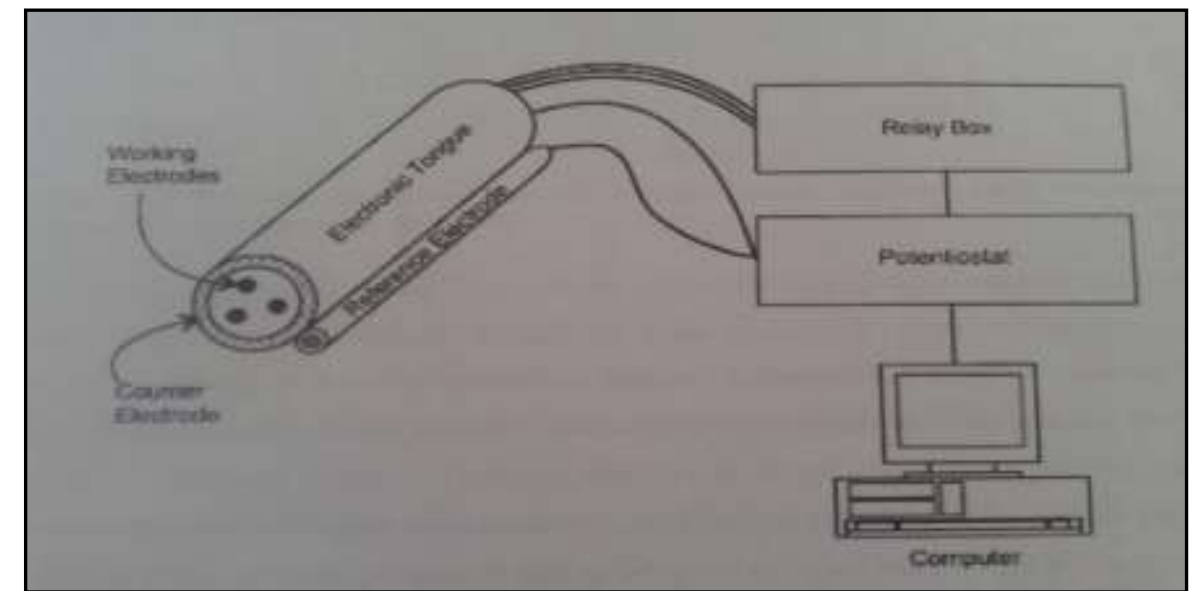

Gambar 2. Skema diagram sensor rasa berdasar voltametrik (Ivarsson et al, 2001)

Sistem pengecap elektronik (electronic tongue) memiliki kekurangan dan kelebihan. Kekurangannya adalah electronic tongue baik yang berdasar potensial maupun yang berdasar voltametrik ini tidak sepenuhnya sama dengan lidah manusia, salah satunya karena semua sampel yang digunakan pada sistem ini harus berupa cairan atau dicaikan terlebih dahulu. Sedangkan kelebihan electronic tongue, pertama, sistem sensor ini dapat bekerja pada suhu dan tekanan tinggi. Kedua, sistem sensor rasa ini lebih sensitif dan akurat dibandingkan dengan lidah manusia (Kaltsum et al, 2009).

Berdasarkan latar belakang tersebut maka dapat dirumuskan beberapa permasalahan yang akan dipecahkan yaitu (1) bagaimana membuat prototipe ion meter dua kanal; (2) bagaimana membuat dua macam membran selektif ion campuran DOP:TOMA dengan perbandingan masing-masing 3:7 dan 9:1. dan (3) bagaimana mengkarakterisasi dua macam membran selektif ion campuran DOP:TOMA dengan perbandingan 3:7 dan 9:1 terhadap sampel lima macam rasa dasar. Penelitian ini dibatasi pada beberapa hal, yaitu (1) Ion meter belum dikalibrasi dan (2) Pemilihan lipid campuran DOP:TOMA belum memperhatikan aspek tertentu; (3) Karakteristik membran selektif ion hanya diuji berdasarkan respon potensial terhadap lima macam sampel yang dianggap mewakili lima rasa dasar dan (4) Suhu larutan uji dan ruangan dianggap konstan (suhu ruang).

\section{METODE PENELITIAN}

Pada penelitian ini terdiri dari beberapa tahap yang dapat ditunjukkan pada Gambar 3 . Berdasarkan Gambar 3, tahapan penelitian terbagi menjadi beberapa tahap. Tahap pertama dalam penelitian ini adalah membuat elektroda kerja dan ion meter. Dalam pembuatan elektroda kerja yang dilakukan adalah pembuatan kawat $\mathrm{Ag} / \mathrm{AgCl}$. Kemudian dilanjutkan dengan pembuatan ion meter. Ion meter terdiri atas amplifier sebagai penguat tegangan dimana dalam penelitian ini menggunakan op-amp LF412, pemproses sinyal, dan LCD sebagai penampil besarnya nilai tegangan yang terukur. Tahap kedua dalam penelitian ini adalah pembuatan larutan sampel lima rasa dasar. Dimana untuk sampel lima rasa dasar menggunakan glukosa untuk mewakili rasa manis, $\mathrm{HCl}$ untuk mewakili rasa asam, $\mathrm{KCl}$ untuk mewakili rasa asin, kina untuk mewakili rasa pahit, dan umami untuk mewakili rasa gurih. Tahap ketiga dalam penelitian ini adalah tahap membuat membran. Adapun komposisi penyusun membran seperti yang ditunjukkan pada Tabel 2. 


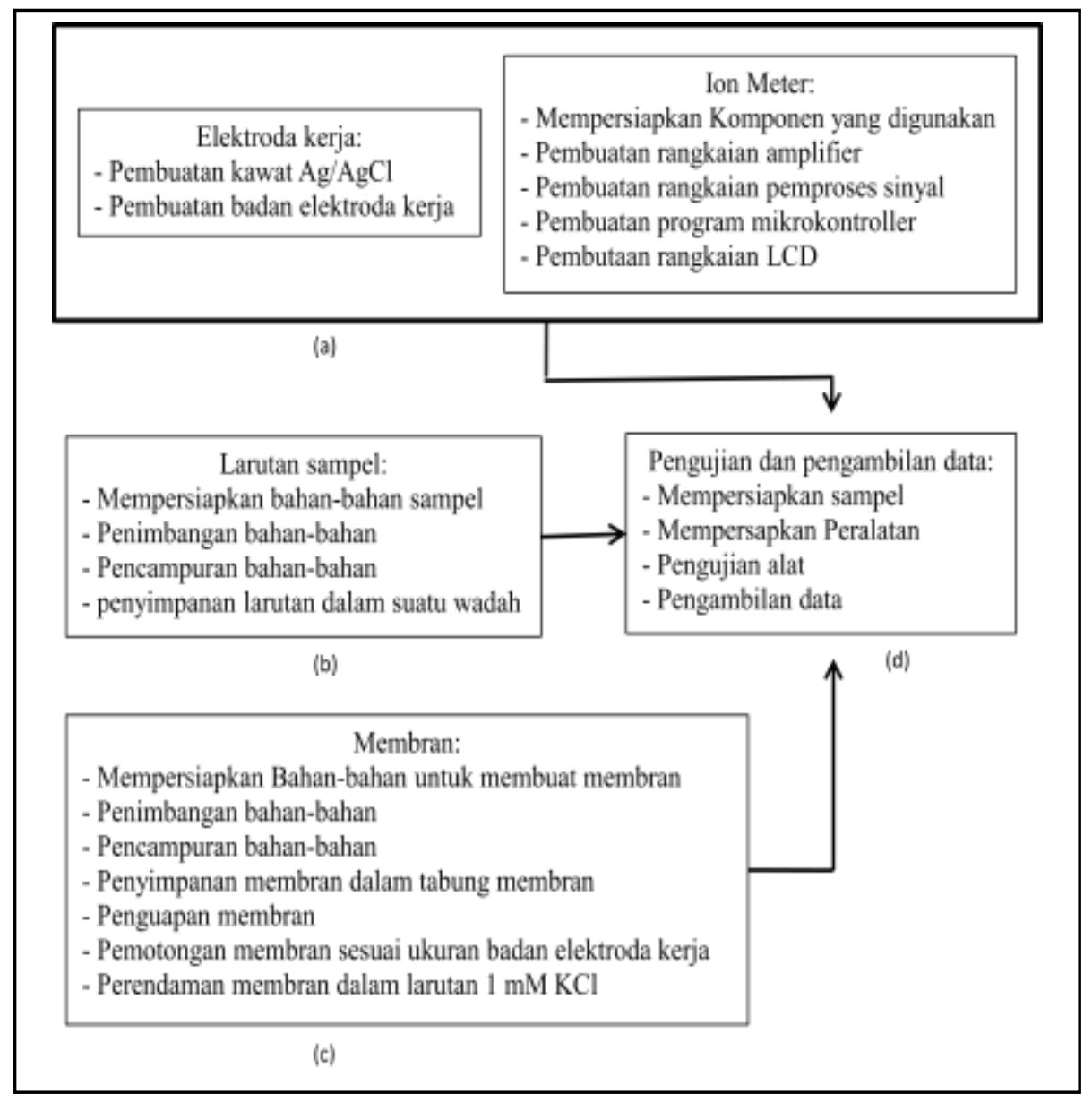

Gambar 3. Tahapan Penelitian (a) Pembuatan eletroda kerja dan ion meter,(b) pembuatan larutan sampel, (c) pembuatan membran, (d) pengujian dan pengambilan data

Tabel 2. komposisi penyusun membran

\begin{tabular}{ccccc}
\hline Membran Lipid & & PVC & O-NPOE & \multirow{2}{*}{ THF } \\
\cline { 1 - 4 } Campuran & $(\%$ massa $)$ & $(\%$ massa $)$ & $(\%$ massa $)$ & \\
\cline { 1 - 4 } DOP : TOMA $=3: 7$ & 8 & 28 & 64 & 3 \\
DOP : TOMA $=9: 1$ & 8 & 28 & 64 & 3 \\
\hline
\end{tabular}

Dan tahapan terakhir yang dilakukan dalam penelitian ini adalah pengujian dan pengambilan data. Adapun langkah-langkah yang dilakukan dalam pengujian dan pengambilan data adalah sebagai berikut:

1. Elektroda referensi dan elektroda kerja dua kanal dimasukkan ke dalam larutan $1 \mathrm{mM}$ $\mathrm{KCl}$ (larutan referensi) sambil diaduk dengan stirrer selama beberapa menit.
2. Kedua elektroda diambil dan dikeringkan dengan tisu.

3. Kedua elektroda dimasukkan kedalam sampel larutan misalnyaglukosa dengan konsentrasi $0,1 \mathrm{mM}$ sambil diaduk dengan stirrer selama \pm 4 menit.

4. Mencatat potensial yang terbaca pada LCD

5. Mengulang langkah penguian no 1 sampai no 4 untuk konsentrasi $0,3 \mathrm{mM}, 1 \mathrm{mM}, 3$ 
$\mathrm{mM}, 10 \mathrm{mM}, 30 \mathrm{mM}, 100 \mathrm{mM}$ untuk jenis rasa yang sama.

6. Mengulag langkah pengujian no 1 sampai 5 untuk pengujian sampel yang lain $(\mathrm{HCl}$, $\mathrm{KCl}$, MSG, kina).

\section{HASIL DAN PEMBAHASAN}

Membran lipid yang digunakan dalam penelitian ini adalah membran lipid campuran
DOP: TOMA dengan perbandingan massa masing-masing 3:7 dan 9:1. Membran lipid dibuat dengan menggunakan campuran bahan kimia yaitu: lipid, PVC, THF, plasticizer dengan perbandingan tertentu dan ditempatkan pada tabung membran. Setelah itu tabung membran disimpan selama semalaman. Membran lipid yang terbentuk seperti yang tampak pada Gambar 5.

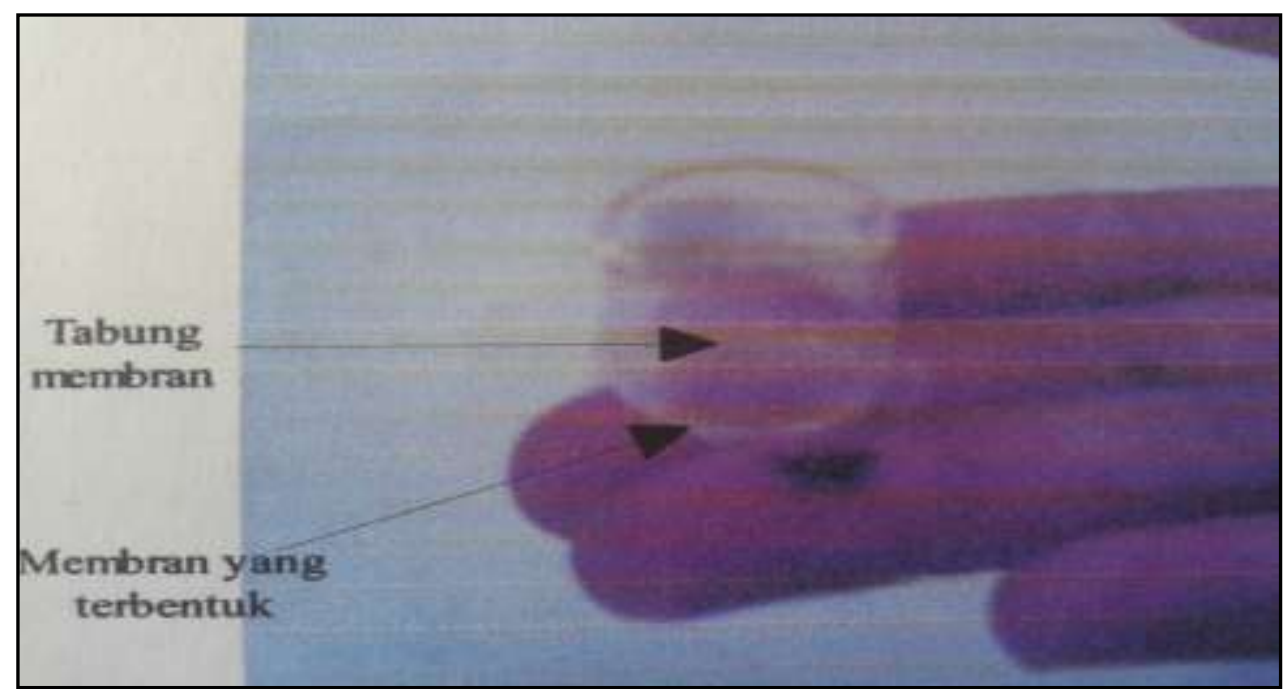

Gambar 4. Membran lipid yang terbentuk

Ion meter yang telah dibuat kemudian diuji menggunakan membran lipid campuran DOP:TOMA dengan perbandingan masingmasing 3:7 dan 9:1. Membran yang telah dibuat berfungsi untuk mengukur secara kuantitatif suatu rasa pada larutan sampel. Informasi rasa yang dikandung, diubah oleh lipid menjadi bentuk potensial listrik. Potensial listrik yang terbentuk akan diperkuat oleh amplifier yang ada dalam ion meter yang telah dibuat. Kemudian potensial listrik yang dihasilkan akan ditampilkan pada LCD. Adapun hasil hasil pengukuran dengan menggunakan membran lipid campuran DOP:TOMA dengan perbandingan 3:7 seperti di Tabel 3. Dan hasil pengukuran dengan menggunakan membran lipid campuran DOP:TOMA dengan perbandingan 9:1 di Tabel 4. 
Amalinda, F. 2016. Analisis Pola Keluaran Prototipe Sensor Rasa Portable Campuran Lipid Dioctyl Phosphate dan Trioctyl Methyl Ammonium Chloride Journal of Sainstek 8(1): 20-30

Tabel 3. Hasil pengukuran menggunaan membran lipid DOP:TOMA = 3:7

\begin{tabular}{cccccc}
\hline \multirow{2}{*}{ Konsentrasi $(\mathrm{mM})$} & \multicolumn{5}{c}{ Potensial $(\mathrm{mV})$} \\
\cline { 2 - 6 } & $\mathrm{HCl}$ & Glukosa & $\mathrm{KCl}$ & Kina & MSG \\
\hline 0,1 & 40 & & 96 & 32 & 37 \\
0,3 & 34 & & 95 & 23 & 28 \\
1 & 29 & & 90 & 20 & 20 \\
3 & 28 & -2 & 89 & 17 & 19 \\
10 & 18 & -3 & 82 & 15 & 15 \\
30 & 17 & -6 & 78 & 10 & 14 \\
100 & 6 & -7 & 67 & 9 & 9 \\
\hline
\end{tabular}

Tabel 4. Hasil pengukuran menggunaan membran lipid DOP:TOMA = 9:1

\begin{tabular}{cccccc}
\hline \multirow{2}{*}{ Konsentrasi $(\mathrm{mM})$} & \multicolumn{5}{c}{ Potensial $(\mathrm{mV})$} \\
\cline { 2 - 6 } & $\mathrm{HCl}$ & Glukosa & KCl & Kina & MSG \\
\hline 0,1 & & & 167 & 19 & 13 \\
0,3 & 21 & & 168 & 28 & 14 \\
1 & 25 & & 169 & 44 & 18 \\
3 & 32 & -5 & 170 & 54 & 21 \\
10 & 41 & 6 & 171 & 56 & 24 \\
30 & 65 & 19 & 178 & 57 & 27 \\
100 & 80 & 21 & 190 & 62 & 30 \\
\hline
\end{tabular}

Profil respon dari kedua membran lipid campuran DOP:TOMA masing-masing dengan perbandingan 3:7 dan 9:1 untuk setiap sampel rasa dasar yang terukur dapat dengan jelas terlihat pada Gambar 5. Rasa asam diwakili oleh HCl. Dalam suatu larutan, senyawa Hclterionisasi menjadi $\mathrm{H}^{+}$dan $\mathrm{Cl}^{-}$. Berdasarkan gambar diatas, semakin tinggi konsentrasi larutan sampel, profil respon membran lipid campuran 3:7 menunjukkan penurunan. Penurunan potensial dipengaruhi oleh adanya reaksi antara lipid TOMA yang bersifat anionik dengan ion $\mathrm{Cl}^{-}$yang dikandung oleh $\mathrm{HCl}$. Sedangkan untuk membran lipid campuran 9:1 menunjukkan peningkatan. Peningkatan potensialdikarenakan adanya reaksi antara lipid DOP yang bersifat kationik terhadap ion $\mathrm{H}^{+}$.
Untuk larutan sampel rasa asin diperoleh hasil seperti yang diperlihatkan pada Gambar 6 .

Rasa asin diwakili oleh $\mathrm{KCl}$. Dalam suatu larutan, senyawa $\mathrm{KCl}$ terionisasi menjadi $\mathrm{K}^{+}$dan $\mathrm{Cl}^{-}$. Berdasarkan gambar diatas, semakin tinggi konsentrasi larutan sampel, profil respon membran lipid campuran 3:7 menunjukkan penurunan. Penurunan potensial dipengaruhi oleh adanya reaksi antara lipid TOMA yang bersifat anionik dengan ion $\mathrm{Cl}^{-}$ yang dikandung oleh $\mathrm{KCl}$. Sedangkan untuk membran lipid campuran 9:1 menunjukkan peningkatan. Peningkatan potensialdikarenakan adanya reaksi antara lipid DOP yang bersifat kationik terhadap ion $\mathrm{K}^{+}$. Untuk larutan sampel rasa manis diperoleh hasil seperti yang diperlihatkan pada Gambar 7. 


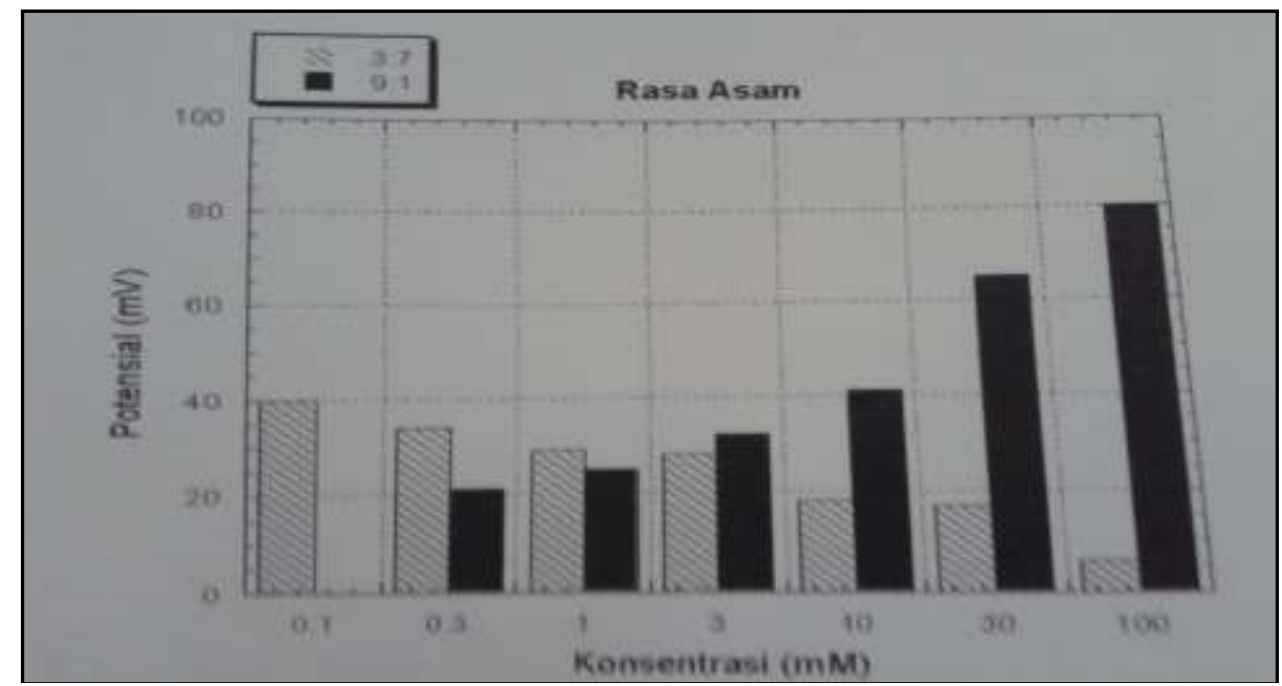

Gambar 5. Profil respon membran lipid campuran 3:7 dan 9:1 terhadap larutan sampel rasa asam

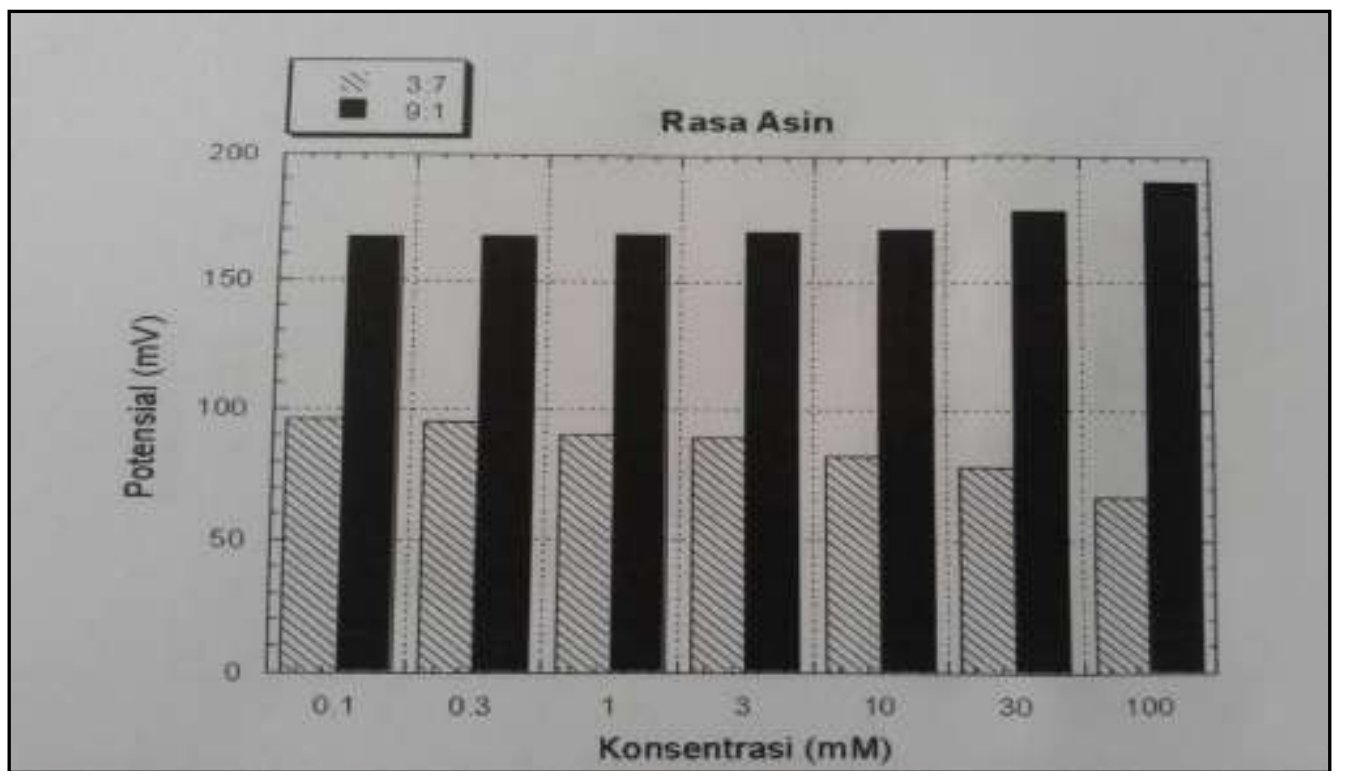

Gambar 6. Profil respon membran lipid campuran 3:7 dan 9:1 terhadap larutan sampel rasa asin 


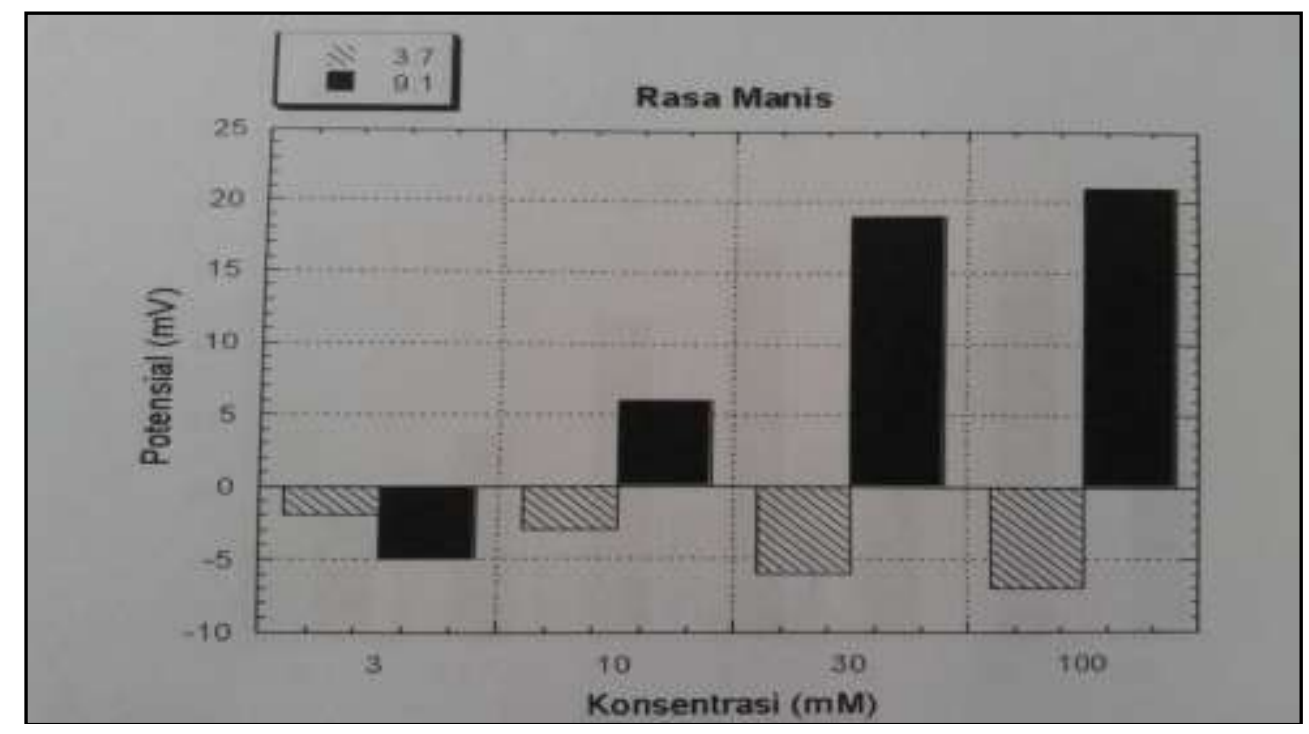

Gambar 7. Profil respon membran lipid campuran 3:7 dan 9:1 terhadap larutan sampel rasa manis

Rasa manis diwakili oleh glukosa $\left(\mathrm{C}_{6} \mathrm{H}_{12} \mathrm{O}_{6}\right)$. Senyawa glukosa merupakan senyawa hidrofilik yang cenderung stabil dalam fasa air, sehingga senyawa ini sulit berinteraksi dengan membran. Hal ini terlihat dengan baru mulai terukurnya potensial sampel glukosa ketika konsentrasi $3 \mathrm{mM}$. Untuk larutan sampel rasa pahit yang diwakili oleh kina $\left(\mathrm{C}_{20} \mathrm{H}_{24} \mathrm{~N}_{2} \mathrm{O}_{2}\right)$, diperoleh hasil seperti yang diperlihatkan pada Gambar 8.

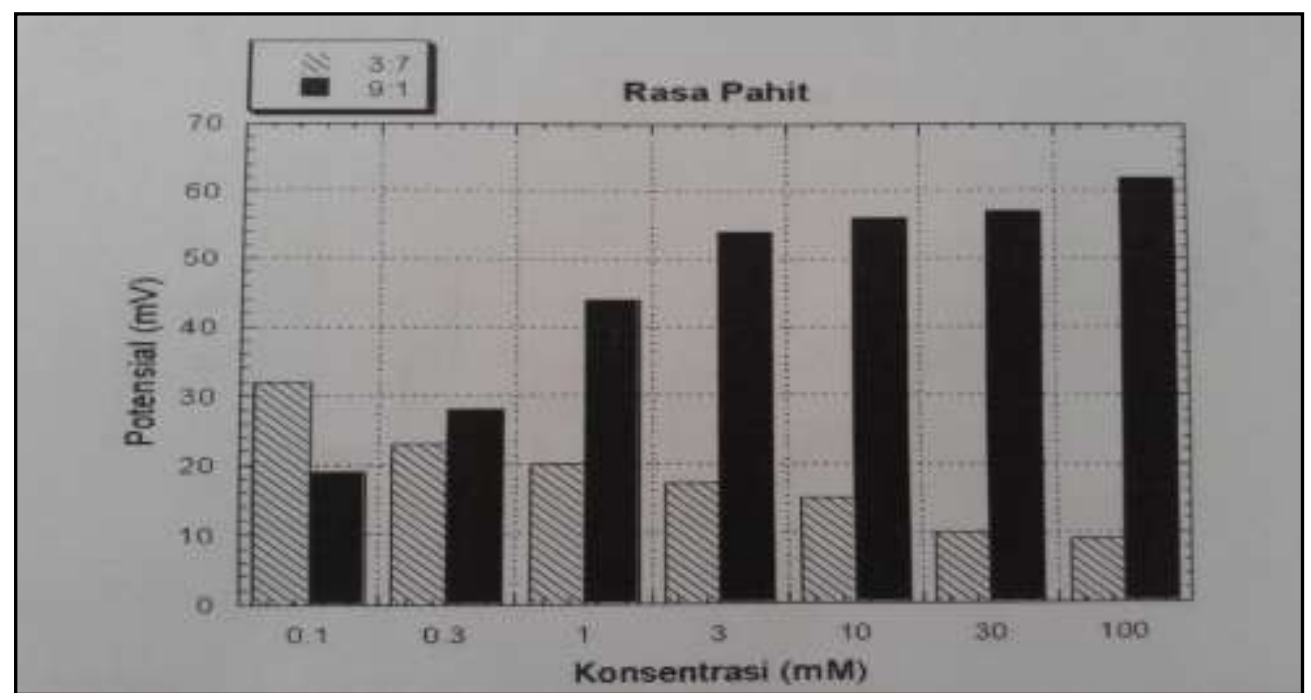

Gambar 8. Profil respon membran lipid campuran 3:7 dan 9:1 terhadap larutan sampel rasa pahit 
Dalam larutan, senyawa kina terionisasi menjadi ion kina dan $\mathrm{OH}^{-}$. Berdasarkan Gambar 8, semakin tinggi konsentrasi larutan sampel, profil respon membran lipid campuran 3:7 menunjukkan penurunan. Penurunan potensial dipengaruhi oleh adanya reaksi antara lipid TOMA yang bersifat anionik dengan ion $\mathrm{C}_{20} \mathrm{H}_{24} \mathrm{~N}_{2} \mathrm{O}_{2} \mathrm{H}^{+}$yang dihasilkan dari reaksi sebelumnya antara kina dengan air. Sedangkan untuk membran lipid campuran 9:1 menunjukkan peningkatan. Peningkatan potensial dikarenakan adanya reaksi antara lipid DOP yang bersifat kationik terhadap ion $\mathrm{OH}^{-}$ yang juga dihasilkan dari reaksi sebelumnya antara kina dengan air. Untuk larutan sampel rasa umami yang diwakili oleh MSG $\left(\mathrm{C}_{5} \mathrm{H}_{8} \mathrm{NnaO}_{4}\right)$, diperoleh hasil seperti yang diperlihatkan pada Gambar 9.

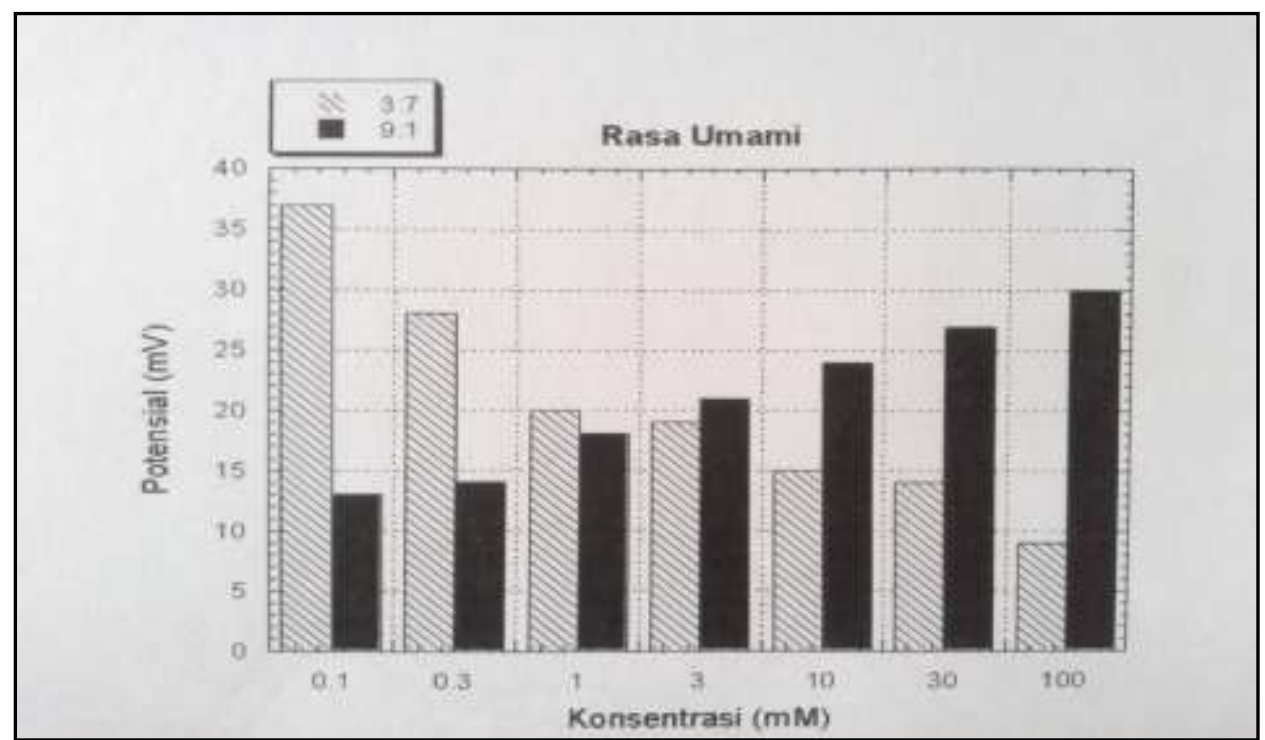

Gambar 9. Profil respon membran lipid campuran 3:7 dan 9:1 terhadap larutan sampel rasa umami

Berdasarkan Gambar 9, terlihat bahwa untuk rasa umami yang diwakili oleh MSG, semakin tinggi konsentrasi larutan sampel, profil respon membran lipid campuran 3:7 menunjukkan penurunan. Penurunan potensial dipengaruhi oleh adanya reaksi antara lipid TOMA yang bersifat anionik dengan ion $\mathrm{C}_{5} \mathrm{H}_{8} \mathrm{NO}_{4}^{-}$yang yang dikandung oleh MSG. Sedangkan untuk membran lipid campuran 9:1 menunjukkan peningkatan. Peningkatan potensial dikarenakan adanya reaksi antara lipid DOP yang bersifat kationik terhadap ion $\mathrm{Na}^{+}$.

\section{KESIMPULAN}

Berdasarkan hasil penelitian, maka dapat diambil beberapa kesimpulan antara lain:

1. Telah dibuat membran lipid campuran DOP:TOMA dengan perbandingan massa masing-masing 3:7 dan 9:1. Membran lipid ini telah diujikan pada larutan sampel penghasil lima rasa dasar dimana setiap rasa terbagi menjadi tujuh variasi konsentrasi.

2. Membran lipid dengan perbandingan DOP:TOMA $=3: 7$ didominasi oleh lipid TOMA, oleh karenanya membran lipid ini respon terhadap anion sampel.

$$
\mathrm{R}_{4} \mathrm{~N}^{+} \mathrm{Cl}^{-}{ }_{(\text {membran })}+\mathrm{X}^{-}{ }_{(\text {aq })} \longleftrightarrow \mathrm{R}_{4} \mathrm{~N}^{+} \mathrm{X}^{-}
$$


Ketika diujikan pada sampel penghasil lima rasa dasar, membran lipid ini menghasilkan besar potensial yang mengalami penurunan untuk setiap kenaikan konsentrasi.

3. Membran lipid dengan perbandingan DOP:TOMA = 9:1 didominasi oleh lipid DOP, oleh karenanya membran lipid ini respon terhadap kation sampel.

$$
\begin{array}{r}
2(\mathrm{RO})_{2} \mathrm{PO}_{2} \mathrm{H}_{\text {(membran) }}+\mathrm{M}^{+}{ }_{\text {(aq) }} \longleftrightarrow \\
\left.\mathrm{O}_{2} \mathrm{PO}_{2}\right)_{2} \mathrm{M}^{+}{ }_{\text {(membran) }}+\mathrm{H}^{+}{ }_{\text {(aq) }}
\end{array}
$$

Ketika diujikan pada sampel penghasil lima rasa dasar, membran lipid ini menghasilkan besar potensial yang mengalami kenaikan untuk setiap kenaikan konsentrasi.

\section{DAFTAR KEPUSTAKAAN}

Deng S, Tian S dan Chen ZX. 2008. Multifrequency large amplitude pulse voltammetry: a novel electrochemical method for electronic tongue, Sensor and Actuators B 123, 1049-1056.

Habara M, Toko K dan Ikezaki H. 2003. Study Of sweet taste evaluation using taste sensor with lipid/polymer membranes, Biosensors and Bioelectronics, 15591563.

Ivarsson P, Hojer N, Holmin S, Krantz-Rulcker $C$ dan Winguist F. 2001. Discrimination of tea by means of a voltammetric electronic tongue and different applied waveforms, Sensor and Actuator B, 449454.

Kaltsum U, Triyana K dan Siswanta D. 2009. Fabrication and Characterization of Membrane Based on Taste Sensor to Classify Five Types of Basic Taste, Proc, ISSTEC 2009, 301.

Soderstrom C, Winguist F dan Krantz-Rulcker C. 2003. Recognition of Six Microbial Species with an Electronic Tongue, Sens. Actuators B (Chem.) B89 (3), 248-255.

Toko K, Imamura T, Yanagizawa $S$ dan Kume T. 1996. Monitoring of Fermentation Process of Miso (soybean paste) using multichannel taste sensor, Sensor and Actuators B 37, 179-185.

Winguist F, Wide P dan Lundstorm I. 1997. An electronic tongue based on voltametry, Anal. Chim, Acta 375, 21-31.

Winguist F, Bjorklund R, Krantz-Rulcker C, Lundstroma I, Stergren K dan Skoglund T. 2005. An Electronic Tongue in the Dairy Industry, Sensors and Actuators B 111-112, 299-304.

Zheng J dan Melissa P. 2006. Taste Masking Analysis in Pharmaceutical Formulation Development Using an Electronic Tongue, International Journal of Pharmaceutics, 310, 118-124. 